\title{
Bruno Petey-Girard, Vigenère, Desportes et la «divine Poësie et Musique» des psaumes
}

\section{Filippo Fassina}

\section{Q OpenEdition}

1 Journals

\section{Edizione digitale}

URL: http://journals.openedition.org/studifrancesi/9845

DOI: 10.4000/studifrancesi.9845

ISSN: 2421-5856

\section{Editore}

Rosenberg \& Sellier

\section{Edizione cartacea}

Data di pubblicazione: 1 octobre 2007

Paginazione: 430

ISSN: 0039-2944

\section{Notizia bibliografica digitale}

Filippo Fassina, «Bruno Petey-Girard, Vigenère, Desportes et la «divine Poësie et Musique» des psaumes», Studi Francesi [Online], 152 (LI | II) | 2007, online dal 30 novembre 2015, consultato il 09 janvier 2021 URL: http://journals.openedition.org/studifrancesi/9845; DOI: https://doi.org/10.4000/studifrancesi. 9845

Questo documento è stato generato automaticamente il 9 janvier 2021.

\section{(c) 9 (i) $\Theta$}

Studi Francesi è distribuita con Licenza Creative Commons Attribuzione - Non commerciale - Non opere derivate 4.0 Internazionale. 


\title{
Bruno Petey-Girard, Vigenère, Desportes et la «divine Poësie et Musique» des psaumes
}

\author{
Filippo Fassina
}

\section{NOTIZIA}

BRUNO PETEY-GIRARD, Vigenère, Desportes et la «divine Poësie et Musique» des psaumes, «Bibliothèque d'Humanisme et Renaissance», LXVIII, 3 (2006), pp. 499-516.

1 L'A. esamina una serie di opere di Blaise de Vigenère (De la Penitence et de sesparties, Pseaumes [...] tornez en prose mesurée, un Psaultier de David torné en prose mesurée ou vers libres e Des prieres et oraisons) e di Philippe Desportes (una nuova edizione delle Premieres Cuvres, un Psautier ampliato in varie edizioni successive) che, in un arco di tempo che va dal 1587 al 1603, si configurano essenzialmente come traduzioni di salmi. Entrambi gli autori ottennero l'approvazione ecclesiastica e senza dubbio, in accordo con la liturgia latina cattolica, erano musicate, così come lo erano in tutta la tradizione francese da Marot a Jean-Antoine de Baïf). Petey-Girard affronta dunque il problema della musica e della traduzione all'interno del salterio: a differenza dei Calvinisti che adottano una partizione musicale basata sul canto, Vigenère, nel passaggio dal verso alla prosa, sceglie una prosa cadenzata che tenderebbe alla musicalità della lettura $\mathrm{e}$ richiamerebbe nel migliore dei modi il verso ebraico, offrendo anche un notevole impatto emozionale ed etico. Ma l'insuccesso di questa scelta porta il traduttore a scegliere una lettura più spirituale dei salmi. Desportes invece, pur partendo dalle riflessioni di Vigenère, preferisce una via puramente poetica applicando una variazione metrica che talora si avvicina alla prosa d'arte, talora raggiunge i più alti livelli di poesia. Lo studioso mette quindi in evidenza lo stretto legame che si viene a creare tra forma metrica e argomento del salmo e tale risultato rende la musicalità dei salmi perfettamente accessibile al pubblico francese. Desportes riesce dunque là dove Vigenère aveva fallito, benché il debito con quest'ultimo sia evidente, e le numerose 
edizioni successive dei CL Pseaumes de David mis en vers françois dimostrano che quest'opera risulterà il punto di riferimento per tutti gli autori-traduttori successivi. 